\title{
CONTRATO DE CORRETAGEM DE IMÓVEIS NA PLANTA E A (IM)POSSIBILIDADE DA COBRANÇA DA TAXA DE CORRETAGEM EM FACE DO COMPRADOR
}

José Barros Correia Júnior* Paula Falcão Albuquerque**

\begin{abstract}
Sumário: Introdução - 1. O contrato de corretagem e a venda de imóveis na planta pelo incorporador - 2. Relação de consumo e o dever de boa-fé - 3. O dever de informação e a cobrança de taxa de corretagem em face do comprador - Consideraçōes finais - Referências.
\end{abstract}

\section{INTRODUÇÃO}

A negociação de imóveis vinculados à incorporação imobiliária é um tipo de avença com particularidades que merecem ser analisadas, especialmente no que se refere à corretagem que é desempenhada para a busca de possíveis compradores para as unidades autônomas.

* Doutor em Constitucionalização das Relações Privadas pela FDR/UFPE. Membro do grupo de pesquisa "Constitucionalização das Relações Privadas" - CONREP da Universidade Federal de Pernambuco. Membro do grupo de pesquisa "Direito Privado e Contemporaneidade" da Universidade Federal de Alagoas. Professor da Graduação e Mestrado da FDA/UFAL. Advogado.

** Mestranda em Direito pela FDA/UFAL. Membro do grupo de pesquisa "Constitucionalização das Relações Privadas” - CONREP da Universidade Federal de Pernambuco. Membro do grupo de pesquisa "Direito Privado e Contemporaneidade" da Universidade Federal de Alagoas. Professora de Direito. Advogada. 
Em geral, a atividade desses corretores é desenvolvida em estandes de vendas da própria incorporadora, que se organiza fisicamente para receber pretensos compradores e os convencer das vantagens de adquirir os bens objetos de venda. Quando da apresentação dos produtos e por quanto eles podem ser adquiridos, é habitual que os corretores apresentem os valores finais para compra, incluindo o valor da comissão de corretagem, sem, contudo, fazer tal especificação no momento da oferta.

Nesse sentido, os consumidores que estão recebendo as informaçôes da oferta apenas recebem o preço cheio, sem o necessário detalhamento sobre o que ele remunera. Em geral, após toda fazer de convencimento e apenas no instante de formalização é que os valores são descritos no contrato. Ou seja, há uma transferência para o consumidor de arcar com todo o serviço de corretagem que é contratado pelo incorporador, de maneira discreta e não ostensiva quando da apresentação da oferta ao público.

O Superior Tribunal de Justiça, em decisão proferida em 2016, aduziu que é válida a cláusula contratual que atribui ao consumidor-comprador o dever de arcar com a remuneração do contrato de corretagem vinculados aos de promessa de compra e venda de unidade autônoma em regime de incorporação imobiliária, desde que previamente informado o preço total da aquisição da unidade autônoma, com o destaque do valor da comissão de corretagem.

Nesse sentido, o presente ensaio pretende responder ao seguinte questionamento: no momento em que um pretenso comprador se dirige ao estande de vendas de um incorporador para celebrar a compra de um "imóvel na planta", ainda que a oferta não descrimine o seu dever de arcar remuneração pela corretagem, é possível cobrar do comprador se descrita no contrato?

Para tanto, inicialmente, será feita uma análise acerca dos contratos de corretagem no Brasil, especialmente os vinculados à incorporação imobiliária. Mais adiante, será apresentado como o ordenamento jurídico brasileiro cuida das relaçôes de consumo para, ao final, cuidar especificamente do dever de informar acerca da comissão devida.

\section{O CONTRATO DE CORRETAGEM E A VENDA DE IMÓVEIS NA PLANTA PELO INCORPORADOR}

O contrato de corretagem não é novidade no Brasil, tampouco algo eventual; ao contrário, existe desde a colonização e é algo bastante corriqueiro nos dias atuais, especialmente no mercado imobiliário. 
Desde a época do Brasil-Colônia já se identificava a existência de intermediadores nas negociaçôes de imóveis; porém, com a chegada da família real nas terras brasileiras e com o desenvolvimento urbano se intensificaram os contratos imobiliários e, por consequência, a preocupação jurídica com o pagamento de retribuição àqueles que intermediavam tais acordos firmados ${ }^{1}$.

Inicialmente, as Ordenações do Reino cuidavam dessas intermediaçôes. A primeira legislação brasileira a reger o profissional da corretagem foi o Código Comercial de 1850, que delineava da profissão de corretor, limitando, porém, seu regramento aos considerados atos de comércio ${ }^{2}$. Foi através da Lei n. $6.530 / 78^{3}$ que a profissão de corretor de imóveis foi juridicamente ampliada para todas as formas de contratação, não se limitando ao campo comercial.

Ocorre que o contrato de corretagem ainda era uma modalidade atípica no Direito Brasileiro, especialmente porque Código Civil de 1916 ou qualquer outra lei não descrevia essa forma de avença com natureza contratual. Apenas com o Código Civil de 2002, o contrato de corretagem - e não apenas a profissão de corretor - passou a ser descrito na legislação, tipificando-o e apresentado os seus contornos jurídicos, através dos seus artigos 722 ao $729^{4}$.

A Codificação Civil afirma que existe o contrato de corretagem quando "uma pessoa, não ligada a outra em virtude de mandato, de prestação de serviços ou por qualquer relação de dependência, obriga-se a obter para a segunda um ou mais negócios, conforme as instruções recebidas"s. Nota-se que é a inexistência de qualquer relação de dependência que faz dessa forma de contratação distinta das outras modalidades contratuais, como os contratos de mandato, de prestação de serviços e outros congêneres.

1 GOLDHAR, Tatiane Gonçalves Miranda. Os novos rumos do contrato de corretagem e sua inserção nos contratos de promessa de compra e venda de imóvel: duas faces de uma mesma moeda. Revista da EJUSE, Aracaju, n. 18, p. 371-391, 2013.

2 Os artigos 36 a 67 do Código Comercial de 1950 cuidavam da profissão de corretor para os negócios mercantis. BRASIL. Código Comercial de 1850. Disponível em: <http://www.planalto.gov. br/ccivil_03/leis/10556-1850.htm>. Acesso em: 28 de abril de 2018.

3 BRASIL. Lei n. 6.530/78. Disponível em: <http://www.planalto.gov. br/ccivil_03/leis/16530. htm>. Acesso em: 28 de abril de 2018.

4 BRASIL. Código Civil de 2002. Disponível em: <http://www.planalto.gov. br/ccivil_03/ leis/2002/110406.htm>. Acesso em: 28 de abril de 2018.

5 Código Civil: Art. 722. Pelo contrato de corretagem, uma pessoa, não ligada a outra em virtude de mandato, de prestação de serviços ou por qualquer relação de dependência, obriga-se a obter para a segunda um ou mais negócios, conforme as instruções recebidas. BRASIL. Código Civil de 2002. Disponível em: <http://www.planalto.gov. br/ccivil_03/leis/2002/110406. htm>. Acesso em: 28 de abril de 2018. 
Ao descrever o contrato de corretagem, Gustavo Tepedino aduz que "a doutrina identifica o contrato de corretagem com a mediação, que se caracteriza pela atividade de aproximação de duas ou mais partes com vistas à conclusão de um negócio de compra e venda"6. Trata-se, portanto, de um negócio em que um intermediador recebe orientações para a busca de pretensos contratantes; o papel do corretor é, portanto, o de aproximar o proponente de algum oblato, fornecendo informações que permitam a conclusão de uma avença7.

A atribuição do corretor tem característica de obrigação de meio, sendo irrelevante se houve ou não êxito na sua celebração do negócio pretendido pelo contratante. Isso porque nem sempre haverá a consecução da avença que se almeja com o contrato de corretagem. Ora, em alguns momentos, o proponente e o destinatário que foram aproximados pelo corretor celebrarão um negócio jurídico, encontrando condições que agradem a ambos; de outro lado, em outras oportunidades, isso pode não acontecer ${ }^{8}$.

Essa modalidade contratual possui como características: a) a consensualidade, em razão de sua formação ocorrer a partir do consenso das partes, ainda que não haja atuação do corretor; b) bilateralidade, tendo em vista a existência de obrigações e contraprestaçôes para ambas as partes; c) onerosidade, pela possibilidade de existir retribuição pelos serviços prestados; d) inexistência de solenidade de forma; e) acessoriedade, porque sua existência está vinculada a busca de outro contrato; f) aleatoriedade, haja vista o fato de que, em geral, o direito à comissão do corretor depende de evento futuro e incerto9. Através dessas características, pode-se notar a intermediação de interesses pelo corretor, visando a um retorno financeiro.

O contrato de corretagem descrito no Código Civil é gênero, que possui como espécies a corretagem oficial e a corretagem livre. A primeira espécie de corretagem é aquela destinada apenas aos corretores investidos de ofício público, isto é, aqueles que possuem prerrogativas imanentes ao exercício de tal função e gozam de fé pública $^{10}$. Esta espécie é dividida em seis classes: a) fundos públicos; b) mercadorias; c) navios; d) operações de câmbio; e) seguros; f) valores; tendo requisitos especiais

6 TEPEDINO, Gustavo. Temas de direito civil. Rio de Janeiro: Renovar, 1999, p. 122.

7 PEREIRA, Caio Mário da Silva. Instituiçôes de Direito Civil: Contratos. v. 3. 21. ed. Rio de Janeiro: Forense, 2017.

8 USTÁRrOZ, Daniel. Contratos em espécie. São Paulo: Atlas, 2015.

9 JUNQUEIRA, Gabriel José Pereira. Corretagem e transação imobiliária no Código Civil. São Paulo: Edipro, 2014.

10 GAGLIANO, Pablo Stolze; PAMPLONA FILHO, Rodolfo. Novo curso de direito civil: contratos em espécie. São Paulo: Saraiva, 2014. 
tratados em leis específicas, não podendo ser desenvolvida por qualquer pessoa ${ }^{11}$. Já a segunda espécie de corretagem - qual seja, a livre - é a atribuída a quaisquer outras atividades e pode ser desempenhada por qualquer pessoa capaz, não dependendo de designação oficial ${ }^{12}$.

É justamente na modalidade de corretagem livre que se inclui a imobiliária. A lei que cuida do assunto é a já mencionada Lei n. 6.530/1978, que foi regulamentada pelo Decreto n. 81.871/1978 e traz alguns contornos para a atuação do intermediador nas compra e venda de bens imóveis.

A corretagem imobiliária é feita por profissionais que possuem autonomia e que não deve manter qualquer vínculo empregatício com as imobiliárias, as incorporadoras ou as construtoras. A atuação dos corretores deve sempre ser fundada de boa-fé e destinada a proteger os interesses tanto do proponente, como do oblato. Assim, "os corretores desempenham função de inegável relevância para o mercado imobiliário na medida em que oportunizam às partes um espaço favorável à negociação a fim de que, no exercício da autonomia de suas vontades, optem por entabular o negócio jurídico pretendido"13.

Entretanto, a corretagem imobiliária não se limita apenas a compra e venda de imóveis já construídos e aptos a morar, podendo tratar, inclusive, de contratos de compra e venda dos chamados "imóveis na planta" objetos de uma incorporação imobiliária. Esta incorporação pode ser entendida como um negócio jurídico em que o incorporador se obriga a realizar, por si ou por terceiros, a construção de unidades imobiliárias em edificação coletiva e, bem assim, a transmitir a propriedade e a posse dessas unidades aos respectivos adquirentes; em contrapartida, obrigam-se os adquirentes a pagar o preço das unidades que se comprometeram a adquirir ${ }^{14}$.

Trata-se, portanto de uma modalidade de avença, regida pela Lei n. $4.591 / 64^{15}$, em que o incorporador de um terreno objetiva a venda de unidades

11 TARTUCE, Flávio. Direito civil: teoria geral dos contratos e contratos em espécie. v. 3 12. ed. rev., atual. e ampl. Rio de Janeiro: Forense, 2017, p. 597.

12 GAGLIANO, Pablo Stolze; PAMPLONA FILHO, Rodolfo. Novo curso de direito civil: contratos em espécie. São Paulo: Saraiva, 2014.

13 BORGES, Marcus Vinícius Motter; RODRIGUES, Luiza Silva. A corretagem na incorporação imobiliária: limites e possibilidades à luz dos precedentes vinculantes definidos pelo Superior Tribunal de Justiça em Recurso Especial Repetitivo (Temas 9383 939). Revista de Direito Civil Contemporâneo, vol. 14/2018, p. 179 - 206, Jan.-mar./2018.

14 CHALHUB, Melhim Namem. O contrato de incorporação imobiliária sob a perspectiva do Código de Defesa do Consumidor. Revista de Direito Imobiliário, São Paulo, v. 24, n. 50, p. 92 - 135, jan.-jun. 2001.

15 BRASIL. Lei n. 4.591/64. Disponível em: <http://www.planalto.gov. br/ccivil_03/leis/14591. htm>. Acesso em: 28 de abril de 2018. 
autônomas imobiliárias ainda em construção, que farão parte de edificações cole$\operatorname{tivas}^{16}$. Para conferir segurança ao processo de incorporação, as vendas das unidades autônomas, durante a construção do imóvel coletivo, apenas poderá ocorrer depois que for realizado o registro da incorporação no cartório de registro de imóveis competente.

A partir desse momento, admite-se a possibilidade de realização de contrato de corretagem junto a agências imobiliárias e/ou corretores autônomos para que se possa promover a intermediação e a eventual comercialização das unidades, conhecidas como "imóveis na planta”. Nesse sentido, através da intelecção de interesses da incorporadora e dos compradores, dá-se a venda das partes autônomas do empreendimento.

Ocorre que, por vezes, a oferta aos pretensos compradores desses imóveis na planta é realizada em estandes de venda com propagandas do próprio incorporador, através de pessoas que não deixam clarividente aos oblatos se estão ali como corretores ou simples divulgadores sob subordinação do vendedor. Ou seja, aqueles que se dirigem aos estandes de venda - os consumidores -, por vezes, não conseguem distinguir se estão recebendo informações de um corretor de imóveis ou de um agente da equipe de vendas do incorporador.

Em que pese a atividade de comercialização de "imóveis na planta”, em geral, não fazer parte do seu objeto social do incorporador, essa informação não é de conhecimento irrestrito da coletividade, razão pela qual, não é esperado que aqueles que se dirigem aos estandes de venda já detenham essa informação. $\mathrm{Na}$ verdade, a maioria dos que procuram informações sobre tais bens não conhecem tal regra.

Em geral, ao se dirigirem os pontos de venda, os consumidores - oblatos recebem a informação de valor total da negociação e as condiçôes de pagamento, sem, contudo, haver a descrição de todos os itens que comporão as prestações devidas. Habitualmente, apenas no instante da formalização da avença é que se apresenta o detalhamento de todos os valores e o quê a estes se vinculam. E é nesse momento - já depois de toda negociação realizada, restando apenas a formalização - que os consumidores se deparam com a informação de que a comissão de corretagem e outros serviços congêneres estão incluídos no valor devido pelo comprador.

16 BORGES, Marcus Vinícius Motter; RODRIGUES, Luiza Silva. A corretagem na incorporação imobiliária: limites e possibilidades à luz dos precedentes vinculantes definidos pelo Superior Tribunal de Justiça em Recurso Especial Repetitivo (Temas 9383 939). Revista de Direito Civil Contemporâneo, vol. 14/2018, p. 179 - 206, jan.-mar./2018. 
Aquele consumidor já fez planos, já se organizou financeiramente e se surpreende com o dever de assumir um encargo financeiro não descrito quando da apresentação da oferta, uma vez que o valor cheio apresentado não descreve a comissão de corretagem. A proteção ao consumidor - que não teve a devida informação durante a oferta - deve prevalecer em face do que está formalizado no contrato (muitas vezes até de difícil interpretação)? $\mathrm{O}$ fato de ter sido informado apenas na formalização escrita é suficiente?

\section{RELAÇÃO DE CONSUMO E O DEVER DE BOA-FÉ}

No Brasil, os consumidores possuem uma atenção especial da Constituição Federal de 1988, que os privilegia ao afirmar, no rol de direitos fundamentais, a necessidade de o Estado promover a proteção ao consumidor ${ }^{17}$, tendo em vista $o$ respeito à dignidade da pessoa humana, elemento que fundamenta a República Federativa do Brasil ${ }^{18}$.

Não apenas no catálogo do art. $5^{\circ}$, a proteção constitucional do consumidor também é identificada quando a $\mathrm{CF} / 88$ cuida da Ordem Econômica brasileira, ofertando caráter principiológico à defesa dos destinatários finais de produtos e serviços ${ }^{19}$.

A necessidade de proteção dos consumidores surgiu em razão da fragilidade daqueles que estão à mercê dos fornecedores de produtos e serviços. Estes fornecedores, em geral, detinham - e continuam tendo - o conhecimento técnico e o poderio econômico capazes de se organizarem para convencer a população de que sua oferta era a melhor possível (ainda que não fosse).

Diante desse contexto, surgiu a necessidade de se atribuir um tratamento apto a minimizar a fragilidade dos destinatários finais. Esta preocupação e salvaguarda,

17 Constituiçãao Federal de 1988: Art. 50 - (...) XXXII - o Estado promoverá, na forma da lei, a defesa do consumidor. BRASIL. Constituição Federal de 1988. Disponível em: <http://www. planalto.gov. br/ccivil_03/leis/14591.htm>. Acesso em: 28 de abril de 2018.

18 Constituição Federal de 1988: Art. 1º A República Federativa do Brasil, formada pela união indissolúvel dos Estados e Municípios e do Distrito Federal, constitui-se em Estado Democrático de Direito e tem como fundamentos: (...) III - a dignidade da pessoa humana. BRASIL. Constituição Federal de 1988. Disponível em: <http://www.planalto.gov. br/ccivil_03/leis/ 14591.htm>. Acesso em: 28 de abril de 2018.

19 Constituição Federal de 1988: Art. 170. A ordem econômica, fundada na valorização do trabalho humano e na livre iniciativa, tem por fim assegurar a todos existência digna, conforme os ditames da justiça social, observados os seguintes princípios: (...) V-defesa do consumidor. BRASIL. Constituição Federal de 1988. Disponível em: <http://www.planalto.gov. br/ccivil_03/leis/14591.htm>. Acesso em: 28 de abril de 2018. 
no Brasil, passaram a ser debatidas a partir da década de 70, entretanto, foi apenas nos anos 80 que se fortaleceu ${ }^{20}$.

Outrora, quando da época do Estado Liberal, o tratamento dado aos fornecedores e consumidores era fundado pelas regras e princípios que envolviam a autonomia da vontade, liberdade de contratar e a mínima intervenção do Poder Público nas relaçôes negociais. Defendia-se a igualdade jurídica formal dos sujeitos contratantes, sendo totalmente irrelevante a existência de qualquer desigualdade fática ou prática de abusos. Inexistia, por conseguinte, qualquer preocupação com a fragilidade das partes, como também, tratamento diferenciado pelo Direito para os consumidores e fornecedores. Ou seja, ambos eram partes do contrato em situação formal de igualdade, a despeito da eventual condição social e econômica, estando mesmo patamar de negociação $0^{21}$.

Entretanto, diante do desenvolvimento tecnológico (processo que surgiu a partir da Revolução Industrial ${ }^{22}$ ), os fornecedores de produtos e serviços começaram a se organizar para atuar com produção em série e fizeram com que a sociedade recebesse em maior quantidade seus objetos de produção, havendo um aumento no mercado de consumo. Ademais, os grandes fabricantes e industriários tinham um poder de organização capaz de estimular o consumo em massa, convencendo as pessoas da necessidade de obtenção e da indispensabilidade dos seus produtos e serviços. Via-se (e ainda vê-se) a disparidade entre fornecedores e consumidores, tanto social como economicamente.

O surgimento Estado Social e, junto com ele, dos princípios que o regem ${ }^{23}$, demonstraram a necessidade de se buscar uma igualdade material nas relações entre as pessoas. Foi com base nesse ideário que o atual Direito do Consumidor se fundou, na intenção de minimizar a alteridade entre as partes. Assim,

o princípio clássico da autonomia da vontade vai ser relativizado por preocupaçóes de ordem social. Tentando harmonizar os interesses envolvidos em uma relação de

20 CAVALIERI FILHO, Sérgio. Programa de direito do consumidor. 3. ed. São Paulo: Atlas, 2011, p. 7.

21 NISHIYAMA, Adolfo Mamoru. A proteção constitucional do consumidor. 2. ed. rev. atual. e ampl. São Paulo: Atlas, 2010, p. 47.

22 Como Aldolfo Mamoru Nishiyama afirma, do início da Revolução Industrial até o surgimento do liberalismo não se imaginava qualquer tipo de proteção jurídica ao consumidor, pois o voluntarismo era característica dessa época. O surgimento do liberalismo trouxe um tratamento formal igualitários entre fornecedor e consumidor. (A proteção constitucional do consumidor. 2. ed. rev. atual. e ampl. São Paulo: Atlas, 2010, p. 48)

23 Tais como os princípios da função social do contrato, boa-fé objetiva e equivalência material. 
consumo, as novas normas de tutela valorizam tanto a vontade como a boa-fé, a segurança e o equilíbrio das relações contratuais ${ }^{24}$.

Vive-se hoje em uma sociedade de consumo onde, constantemente as pessoas recebem informações e são convencidas de que necessitam de mais produtos e serviços, ou seja, estão em constante situação de fragilidade. Isso porque, por vezes a informação repassada aos consumidores não reflete necessariamente a realidade do que se está oferecendo. Há, por vezes, vícios na prestação de informação.

Diante da vulnerabilidade e da importância do consumidor como agente ativo na circulação de riquezas do país, o constituinte originário, como visto acima, inseriu a sua proteção no rol dos direitos e garantias fundamentais. Nesse sentido, o Estado passa a ter o dever de promover e administrar políticas públicas e ações afirmativas aptas a propiciar tal salvaguarda, efetivando a igualdade material e mitigando a disparidade natural existente entre as partes na relação consumerista.

O principal instrumento legal de proteção é o Código de Defesa do Consumidor, que representa para a coletividade a "realização de um direito fundamental (positivo) de proteção do Estado" 25 , confeccionado com o condão de concretizar o princípio da isonomia, da igualdade material. Trata-se de um microssistema legislativo que trouxe um conjunto de princípios que devem ser observados quando da análise das relações consumeristas, dentre eles o da vulnerabilidade do consumidor $^{26}$. Tal reconhecimento demonstra a intenção do CDC em dar um tratamento protetivo à parte mais frágil da relação.

A relação entre o incorporador e os compradores de imóveis na planta é uma típica relação de consumo em que, de um lado, há o fornecedor do imóvel que se organiza para convencer as pessoas da necessidade de adquirir suas unidades autônomas e, do outro lado, estão aqueles que recebem as informações da maneira conveniente pelos e para os proponentes. Para tanto, os primeiros montam estandes de venda e pulverizam toda publicidade para atrair compradores, que, não detém o conhecimento técnico-jurídico acerca das informações que estão sendo ofertadas, ape-

24 MARQUES, Cláudia Lima. Contratos no Código de Defesa do Consumidor. 6. ed. rev. atual, e ampl. São Paulo: RT, 2011, p. 734

25 MARQUES, Claudia Lima; BENJAMIN, Antonio Herman V.; MIRAGEM, Bruno. Comen-

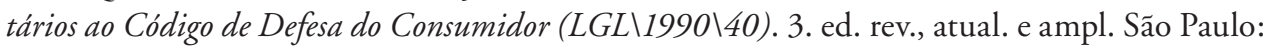
RT, 2010, p. 66.

26 Art. 40 A Política Nacional das Relaçôes de Consumo tem por objetivo o atendimento das necessidades dos consumidores, o respeito à sua dignidade, saúde e segurança, a proteção de seus interesses econômicos, a melhoria da sua qualidade de vida, bem como a transparência e harmonia das relações de consumo, atendidos os seguintes princípios: (...) I - reconhecimento da vulnerabilidade do consumidor no mercado de consumo; 
nas aceitam aquilo que lhes é repassado. Há uma fragilidade em relação aos consumidores e a contratação eventualmente realizada também fica eivada dessa mácula.

Ao analisar os dispositivos inseridos na Codificação Consumerista, percebe-se que o legislador nada mais fez do que aplicar os princípios contratuais do Estado Social. Ora, o olhar tradicional dos vínculos obrigacionais (que limitava os negócios jurídicos à análise unicamente dos elementos subjetivos, objetivos e do vínculo jurídico, como algo transitório e de interesse apenas das partes) não se coaduna com as hodiernas relações obrigacionais - especialmente as que envolvem consumidor -, tendo em vista que, com a mitigação da perspectiva exclusivamente patrimonialista,

se revelou inadequado e insuficiente para tutelar todas as vicissitudes inerentes à visão solidarista da relação obrigacional, que não mais se limita ao resultado da soma de débito e crédito, devendo abandonar tal posição estática para que o vínculo obrigacional seja visto como um processo de cooperação voltado para determinado fim ${ }^{27}$.

Assim, há necessidade de se fazer uma leitura dos negócios jurídicos - inclusive o que venda de imóveis na planta, que é objeto do presente ensaio - através de uma dimensão social, revelando uma necessária satisfação de todos os interesses postos no negócio, que vão além das cláusulas contratuais. $\mathrm{O}$ cuidado com os contratantes não deve ser limitado às letras do contrato firmado entre o incorporador e o consumidor.

Para tanto, além de observar os princípios individuais dos contratos ${ }^{28}$, deve-se considerar os negócios jurídicos com base nos "princípios contratuais típicos do Estado Social", que são: função social do contrato, da equivalência material do contrato e da boa-fé objetiva ${ }^{29}$.

O princípio da função social do contrato reflete a ideia de que "os interesses individuais das partes do contrato sejam exercidos em conformidade com os interesses sociais, sempre que estes se apresentem. Não pode haver conflito entre eles, pois os interesses sociais são prevalecentes" ${ }^{30}$. Nesse sentindo, realização do negócio

27 EHRHARDT JR. Relação Obrigacional como processo na construção do paradigma dos deveres gerais de conduta e suas consequências. Revista da Faculdade de Direito - UFPR. n. 56, Curitiba, p. 141-155, 2012, p. 144-145.

28 Tais como o relatividade dos contratos e da pacta sunt servanda.

29 LÔBO, Paulo. Princípios contratuais. Princípios sociais dos contratos. Revista Jus Navigandi, ISSN 1518-4862, Teresina, ano 18, n. 3750, 7 out. 2013. Disponível em: <https://jus.com.br/ artigos/25359>. Acesso em: 18 mar. 2017.

30 LÔBO, Paulo. Princípios contratuais. Princípios sociais dos contratos. Revista Jus Navigandi, ISSN 1518-4862, Teresina, ano 18, n. 3750, 7 out. 2013. Disponível em: <https://jus.com.br/ artigos/25359>. Acesso em: 18 mar. 2017. 
jurídico (formação e cumprimento), não deve se contrapor aos interesses sociais, afinal estão em patamar de prevalência em face dos interesses individuais. Nas relações de consumo o cumprimento da função social deve ser observado antes mesmo da eventual consecução do negócio, isso porque já desde a oferta ao público não se deve ter como prevalente o interesse do fornecedor que, no caso em análise do presente ensaio diz respeito aos incorporadores. Os incorporadores devem agir em prol do interesse coletivo, respeitando a forma de divulgação de produtos e serviços de maneira adequada a ponto de não gerar prejuízos ao grupo de pessoas que estão na iminência de adquirirem as unidades imobiliárias.

O princípio da equivalência material está inserido na função social do contrato. Independente de se considerá-lo como princípio ou tentáculo da função social, a ideia de equilíbrio contratual deve ser observada em qualquer avença. Isso porque, não se admite prestações desproporcionais, tendo em vista que "o desequilíbrio mostrou-se insuportável para a visão do contrato contemporâneo, com a superação da concepção simplesmente liberal" ${ }^{\prime \prime}$.

O outro princípio que deve ser observado nas relações e, talvez, o mais utilizado para fundamentar a discussão do presente, é o da boa-fé objetiva, que significa

uma atuação refletida, pensando no outro, no parceiro contratual, respeitando seus interesses legítimos, suas expectativas razoáveis, seus direitos, agindo com lealdade, sem abuso, sem obstrução, sem causar lesão ou desvantagem excessiva, cooperando para atingir o bom fim das obrigações: o cumprimento do objetivo contratual e a realização dos interesses das partes ${ }^{32}$.

Tem-se, portanto, que a boa-fé objetiva impõe limites de conduta aos contratantes, exigindo deles a abstenção de prática de condutas abusivas. Dentre os princípios que regem as relações consumeristas está o princípio da boa-fé, inserido textualmente no CDC, quando este trata da Política Nacional das Relaçóes de Consumo, especificamente no art. $4^{\mathrm{o}}$, inciso III $^{33}$. Este comando legal impóe que

31 HIRONAKA, Giselda Maria Fernandes. Principiologia contratual e a valoração ética no Código Civil Brasileiro. Civilistica.com. Revista eletrônica de Direito Civil. ISSN 2316-8374, a.3. n. 1, 2014, p. 9 .

32 GOMIDE, Alexandre Junqueira. A teoria do adimplemento substancial e o princípio da segurança jurídica. Revista de Direito Privado. vol. 45/2011, p. 71-87, jan.-mar./2011, p. 75.

33 Art. 40 A Política Nacional das Relações de Consumo tem por objetivo o atendimento das necessidades dos consumidores, o respeito à sua dignidade, saúde e segurança, a proteção de seus interesses econômicos, a melhoria da sua qualidade de vida, bem como a transparência e harmonia das relações de consumo, atendidos os seguintes princípios: (...) III - harmonização dos interesses dos participantes das relações de consumo e compatibilização da proteção do consumidor com a necessidade de desenvolvimento econômico e tecnológico, de modo a 
as relações entre fornecedor e consumidor devem ser pautadas na boa-fé e no equilíbrio e foi fundado na solidariedade social prevista na Constituição Federal de 1988.

Nesse sentido, o dever de agir com boa-fé, posto literalmente no comando acima mencionado, é destinado tanto aos fornecedores como aos consumidores, afinal "as partes, nas relações contratuais, devem manter posturas de cooperação, transparência e lealdade recíprocas, de modo a respeitar as legítimas expectativas geradas no outro" ${ }^{34}$. É transparência que se espera do incorporador no instante de divulgação dos seus produtos.

Trata-se de um dever geral de conduta ${ }^{35}$ que tem que ser observado por ambas as partes antes mesmo da realização do negócio, durante a sua consecução e em momento posterior.

A boa-fé objetiva estabelece limites aos contratantes, impondo um dever de abstenção de prática de condutas abusivas e desproporcionais. Cláudia Lima Marques $^{36}$ afirma que a boa-fé objetiva

significa atuação refletida, uma atuação refletindo, pensando no outro, no parceiro contratual, respeitando seus interesses legítimos, suas expectativas razoáveis, seus direitos, agindo com lealdade, sem abuso, sem obstrução, sem causar lesão ou desvantagem excessiva, cooperando para atingir o bom fim das obrigações: o cumprimento do objetivo contratual e a realização dos interesses das partes.

Ou seja, é um dever de conduta que atribui ao homem um comportamento honesto probo, leal e equilibrado, fazendo-se a observância de atuação de maneira socialmente aceitável capaz de estabelecer uma confiança legal entre as partes ${ }^{37}$. Assim, é dever tanto do consumidor como do fornecedor a adoção expedientes que demonstrem a intenção de agir honestamente, que revelem o ânimo de colaborar

viabilizar os princípios nos quais se funda a ordem econômica (art. 170, da Constituição Federal), sempre com base na boa-fé e equilíbrio nas relações entre consumidores e fornecedores;

34 Trecho retirado do acórdão proferido pelo Superior Tribunal de Justiça, no Recurso Especial n. 1613644/SP, que tratava acerca de legítima expectativa e boa-fé nas relações de consumo. (Rel. Ministro RICARDO VILLAS BÔAS CUEVA, TERCEIRA TURMA, julgado em 20/09/2016, DJe 30/09/2016).

35 EHRHARDT JÚNIOR, Marcos. Relação obrigacional como processo na construção do paradigma dos deveres gerais de conduta e suas consequências. In: Revista da Faculdade de Direito-UFPR, Curitiba, n. 56, p. 141-155, 2012.

36 MARQUES, Cláudia Lima. Contratos no Código de Defesa do Consumidor. 6. ed. rev. ampl. e atual. São Paulo: RT, 2011, p. 216.

37 MARTINS-COSTA, Judith. A boa-fé no direito privado: sistema e tópica no processo obrigacional. São Paulo: RT, 1999, p. 126. 
para a boa relação contratual, desde as tratativas negociais, durante a confecção do contrato, o cumprimento, até a fase pós-contratual ${ }^{38}$. Nesse sentido, não obstante a boa-fé objetiva estar expressa nos textos legais, esta "é vista como um princípio atualmente positivado, mas antes extralegal" 39 .

A boa-fé objetiva como modelo comportamental faz gerar alguns deveres gerais de conduta para as partes, tais como o dever de proteção, de informação e de lealdade, como aponta Marcos Ehrhardt Júnior ${ }^{40}$.

O que se questiona é o fato de que, quando o incorporador organiza seu estande para vender suas unidades imobiliárias sem deixar claro - durante a oferta ao público - que o faz através de corretagem, age de boa-fé e cumpre seu dever de informar durante a oferta.

\section{O DEVER DE INFORMAÇÃO E A COBRANÇA DE TAXA DE CORRETAGEM EM FACE DO COMPRADOR}

A partir do momento em que se realiza a compra e venda de "imóveis na planta" através de uma corretagem, nasce o direito de o corretor receber a remuneração que lhe é devida, a chamada comissão de corretagem, como prevê o Código Civil, em seu artigo $725^{41}$. Porém, esse contrato de corretagem deve ser feito de maneira tal que possibilite aos comprador e vendedor saberem que por um corretor estão sendo intermediados.

Por vezes, isso só é descoberto pelo comprador no momento em que formaliza o contrato e percebe que a ele está sendo atribuindo o dever de arcar com a retribuição financeira do contrato de corretagem, inicialmente, feito pelo incorporador. Isso porque, durante a oferta, a prestação de informação não é suficiente e clara. Em geral, não se descreve a composição da prestação devida quando se oferece o imóvel na planta; ou seja, limita-se apenas ao dever de avisar acerca do valor final

38 LÔBO, Paulo Luiz Netto. Princípios sociais dos contratos no Código de Defesa do Consumidor e no Novo Código Civil. In: Revista de Direito do Consumidor. vol. 42/2002, p. 187-195, abri-jun/2002.

39 BORGES, Gustavo Silveira; PASQUAL, Cristina Stringari. O dever de cooperação nas relações contratuais. In: Revista dos Tribunais. vol. 971/2016 | p. 145-164| Set./2016, p. 147.

40 EHRHARDT JR., Marcos. As funçōes da boa-fé e a construção de deveres de conduta nas relaçōes privadas. Pensar, Fortaleza, v. 18, n. 2, p. 551-586, maio/ago. 2013, e-ISSN: 23172150, p. 563.

41 Código Civil: Art. 725. A remuneração é devida ao corretor uma vez que tenha conseguido o resultado previsto no contrato de mediação, ou ainda que este não se efetive em virtude de arrependimento das partes. BRASIL. Código Civil de 2002. Disponível em: <http://www. planalto.gov. br/ccivil_03/leis/2002/110406.htm>. Acesso em: 28 de abril de 2018. 
do pagamento. A descrição detalhada costuma ser feita apenas no instante da formalização do contrato.

Em decisão, o Superior Tribunal de Justiça, em sede de Recurso Especial, tombado sob o número n. 1.599.511 - SP, de relatoria do Ministro Paulo de Tarso Sanseverino, tratou do assunto, afirmando, em síntese, pela

Validade da cláusula contratual que transfere ao promitente-comprador a obrigação de pagar a comissão de corretagem nos contratos de promessa de compra e venda de unidade autônoma em regime de incorporação imobiliária, desde que previamente informado o preço total da aquisição da unidade autônoma, com o destaque do valor da comissão de corretagem ${ }^{42}$.

A decisão em apreço, em que pese ter bem tratado acerca do contrato de corretagem, deixou de levar em consideração o contexto fático que normalmente ocorre quanto da realização das vendas em estandes da incorporadora. Ora, é usual que toda ornamentação do local e, às vezes, até a vestimenta das pessoas que atendem o público tenha sinais distintivos que indicam a vinculação ao incorporador. Em geral, quando o público pede informações de preços, é comum que se apresente o valor cheio do imóvel, incluindo os encargos com a corretagem, sem que haja sua a prévia descriminação durante a oferta ao público.

Ocorre que, "o direito à informação adequada, suficiente e veraz é um dos pilares do direito do consumidor" ${ }^{\prime 3}$. Esse direito à informação não se limita às cláusulas contratuais, devendo ser aplicado desde a confecção da oferta. A oferta ou proposta nada mais é do que

a declaração de vontade direcionada à realização de um contrato [...]. Como o contrato é o acordo entre duas ou mais vontades, é necessário que um dos futuros contraentes tome a iniciativa de propor o negócio, dando início à formação do contrato; ele como que olicita a manifestação de vontade, a concordância do outro contraente (aceitação) ao negócio que está propondo. A oferta é o elemento inicial do contrato ${ }^{44}$.

Sua apresentação deve ser de tal forma que deixe clarividente todos os elementos que estarão presentes no pretenso contrato, especialmente, aqueles que gerarão despesas para o consumidor. O CDC, em seu artigo 31, ao tratar da oferta aos consumidores, aduz que

42 SUPERIOR TRIBUNAL DE JUSTIÇA. Recurso Especial n. 1599511/SP, Rel. do Ministro Paulo de Tarso Sanseverino, Segunda Seção, julgado em 24/08/2016, DJe 06/09/2016.

43 LÔBO, Paulo. A informação como um direito fundamental do consumidor. Revista de Direito do Consumidor, São Paulo, vol. 37/2001, p. 59 - 76, jan.-mar./2001.

44 MARQUES, Claudia; BENJAMIN, Antônio; MIRAGEM, Bruno. Código brasileiro de defesa do consumidor comentado pelos autores do anteprojeto. 2. ed. rev., atual. e ampl. São Paulo: RT. 2006, p. 463. 
a oferta e apresentação de produtos ou serviços devem assegurar informações corretas, claras, precisas, ostensivas e em língua portuguesa sobre suas características, qualidades, quantidade, composição, preço, garantia, prazos de validade e origem, entre outros dados, bem como sobre os riscos que apresentam à saúde e segurança dos consumidores ${ }^{45}$.

Ao afirmar que a oferta deve ter informaçóes precisas e ostensivas, significa dizer que ela deve conter os elementos indispensáveis para que o consumidor possa conhecer e optar pela contratação. Ora, não se pode falar de boa-fé quando se transfere o encargo para o consumidor arcar com valores que costumeiramente são pagos pelos vendedores de imóveis em corretagens feitas sem incorporação, sem ao menos deixar clarividente isso na oferta. Afirmar que o contrato escrito já traz tal informação não é suficiente para se verificar a transparência, clareza, precisão e ostensividade da oferta, afinal não basta apenas informar o preço, mas detalhar o que ele remunera.

A ausência de informação adequada durante a oferta é considerada falha na prestação do serviço, isso porque o dever de informação, como mencionado acima, também surge como tentáculo da boa-fé objetiva e "pressupõe que o consumidor tenha ciência prévia de todas as especificidades do produto ou do serviço para que, no livre exercício de sua vontade, possa optar ou não pela aquisição ou contratação"

Nesse sentido, nas relações de consumo, gera "o dever para o fornecedor de esclarecer ao consumidor sobre todos os elementos do produto ou do serviço" ${ }^{\prime \prime 4}$, isto é, a necessidade de apontar os dados bastantes a permitir a cognoscibilidade que o consumidor necessita para fazer suas escolhas.

Sobre o assunto, Marcos Ehrhardt Júnior afirma que "que impõe às partes a obrigação de advertir, explicar, esclarecer, avisar e prestar contas sempre que se fizer necessário, em especial quando da ocorrência de circunstância ainda desconhecida da outra parte" ${ }^{3 / 8}$, tratando-se, pois, de obrigação de meio de não de resultado. Tem-se da necessidade de informar o suficiente para que consumidor com cognoscibilidade, discernimento e capacidade suficientes possa opinar pela contratação ou não com o serviço de corretagem incluso.

45 BRASIL. Código de Defesa do Consumidor. Disponível em: <http://www.planalto.gov. br/ccivil_03/leis/18078.htm>. Acesso em: 28 de abril de 2018.

46 BORGES, Marcus Vinícius Motter; RODRIGUES, Luiza Silva. A corretagem na incorporação imobiliária: limites e possibilidades à luz dos precedentes vinculantes definidos pelo Superior Tribunal de Justiça em Recurso Especial Repetitivo (Temas 9383 939). Revista de Direito Civil Contemporâneo, vol. 14/2018, p. 179-206, jan.-mar./2018.

47 GARCIA, Leonardo de Medeiros. Direito do Consumidor: Código Comentado e Jurisprudencial. 7. ed.. rev. ampl. atual. Niterói: Impetus, 2011, p. 50.

48 EHRHARDT JR., Marcos. As funções da boa-fé e a construção de deveres de conduta nas relações privadas. Pensar, Fortaleza, v. 18, n. 2, p. 551-586, maio/ago. 2013, e-ISSN: 2317-2150, p. 563. 
No momento em que o consumidor se dirige ao estande de venda do incorporador para verificar a possibilidade de adquirir uma unidade imobiliária autônoma, depare-se com alguém que, em geral, passa as características dos imóveis e os valores finais de pagamento, sem contudo, haver o detalhamento do que compões tais valores finais. Tampouco, é costumeiro que se esclareça que não se trata de um agente subordinado ao incorporador, mas de um corretor que ali está como intermediador das negociações.

Como mencionado acima, em que pese a atividade de venda não ser objeto social do incorporador, essa informação não de conhecimento geral de todos, não é algo que o homem médio consiga facilmente identificar e discernir. Pouco, inclusive, consegue sequer dominar os contornos básicos de um contrato de incorporação imobiliária. Nesse sentido, deveria o incorporador deixar tais informações clarividente desde a proposta e não apenas no instante da formalização do contrato. Há que se respeitar a liberdade do consumidor que conscientemente tomará as decisões acerca da compra do imóvel e dos valores que eventualmente pagará.

\section{CONSIDERAÇÕES FINAIS}

O Superior Tribunal de Justiça, no ano de 2016, posicionou-se acerca da validade de cláusula contratual que transfere ao consumidor comprador o dever de pagar a comissão de corretagem nos contratos de promessa de compra e venda de unidade autônoma em regime de incorporação imobiliária, desde que previamente informado o preço total da aquisição da unidade autônoma, com o destaque do valor da comissão de corretagem.

A decisão se funda em uma liberdade contratual que se divorcia de fato das regras e princípios jurídicos que regem os contratos, em especial as relações de consumo brasileiras. Mais do que em qualquer outra relação contratual, nas relaçóes de consumo o dever de informar com clareza impõe aos contratantes que a ausência ou insuficiência de informação leva à má-fé $\mathrm{da}(\mathrm{s})$ parte(s) no contrato.

A suposta autonomia privada que serviu como fundamento para a decisão do STJ não é absoluta, sofrendo limites e sendo conformada pela função social e boa-fé contratuais. Mesmo sendo a essência do contrato, a autonomia não pode ser levada ao patamar de uma supremacia sobre os demais princípios, sob pena de se levar a um estado de injustiça contratual.

Pelo contrário do que se imagina, a autonomia privada leva ao seu extremo, mais do que trazer uma liberdade para as partes no contrato, quando má utilizada acarreta em profunda injustiça, notadamente para relações de consumo, como a analisada pelo STJ. 
Neste sentido, como afirma Henri Lacoirdaire "entre os fortes e fracos, entre ricos e pobres, entre o senhor e o servo é a liberdade que oprime e a lei que liberta" 49 . A legislação, portanto, é de clareza hialina que falta aos contratos que impõe aos contratantes a cobrança de taxas não informadas no momento de se firmar o contrato, sendo impossível a sua cobrança sem a ofensa à boa-fé objetiva e função social dos contratos.

\section{REFERÊNCIAS}

BORGES, Gustavo Silveira; PASQUAL, Cristina Stringari. O dever de cooperação nas relaçōes contratuais. In: Revista dos Tribunais, vol. 971/2016, p. 145-164, set./2016.

BORGES, Marcus Vinícius Motter; RODRIGUES, Luiza Silva. A corretagem na incorporação imobiliária: limites e possibilidades à luz dos precedentes vinculantes definidos pelo Superior Tribunal de Justiça em Recurso Especial Repetitivo (Temas 9383 939). Revista de Direito Civil Contemporâneo, vol. 14/2018, p. 179-206, jan.-mar./2018.

BRASIL, Superior Tribunal de Justiça. Recurso Especial n. 1599511/SP, Rel. do Ministro Paulo de Tarso Sanseverino, Segunda Seção, julgado em 24/08/2016, DJe 06/09/2016.

CAVALIERI FILHO, Sérgio. Programa de direito do consumidor. 3. ed. São Paulo: Atlas, 2011.

CHALHUB, Melhim Namem. O contrato de incorporação imobiliária sob a perspectiva do Código de Defesa do Consumidor. Revista de Direito Imobiliário, São Paulo, v. 24, n. 50, p. 92 - 135, jan.-jun. 2001.

EHRHARDT JR., Marcos. As funções da boa-fé e a construção de deveres de conduta nas relaçōes privadas. Pensar, Fortaleza, v. 18, n. 2, p. 551-586, maio/ago. 2013, e-ISSN: 2317-2150

EHRHARDT JÚNIOR, Marcos. Relação obrigacional como processo na construção do paradigma dos deveres gerais de conduta e suas consequências. In: Revista da Faculdade de Direito - UFPR, Curitiba, n. 56, p. 141-155, 2012.

GAGLIANO, Pablo Stolze; PAMPLONA FILHO, Rodolfo. Novo curso de direito civil: contratos em espécie. São Paulo: Saraiva, 2014.

GARCIA, Leonardo de Medeiros. Direito do Consumidor: Código Comentado e Jurisprudencial. 7. ed.. rev. ampl. atual. Niterói: Impetus, 2011, p. 50.

GOLDHAR, Tatiane Gonçalves Miranda. Os novos rumos do contrato de corretagem e sua inserção nos contratos de promessa de compra e venda de imóvel: duas faces de uma mesma moeda. Revista da EJUSE, Aracaju, n. 18, p. 371-391, 2013.

GOMIDE, Alexandre Junqueira. A teoria do adimplemento substancial e o princípio da segurança jurídica. Revista de Direito Privado. vol. 45/2011, p. 71-87, jan.-mar./2011, p. 75.

49 LACOIRDAIRE, Henri Dominique. Conferences de Notre-Dame de París. Sagnier et Bray, 1848, p. 246. 
•• Direito Civil: Estudos | Coletânea do XV Encontro dos Grupos de Pesquisa - IBDCivil

HIRONAKA, Giselda Maria Fernandes. Principiologia contratual e a valoração ética no Código Civil Brasileiro. Civilistica.com. Revista eletrônica de Direito Civil. ISSN 23168374, a. 3. n. 1, 2014.

JUNQUEIRA, Gabriel José Pereira. Corretagem e transação imobiliária no Código Civil. São Paulo: Edipro, 2014.

LACOIRDAIRE, Henri Dominique. Conferences de Notre-Dame de París. Paris: Sagnier et Bray, 1848.

LÔBO, Paulo Luiz Netto. A informação como um direito fundamental do consumidor. Revista de Direito do Consumidor, São Paulo, vol. 37/2001, p. 59-76, jan.-mar./2001.

LÔBO, Paulo Luiz Netto. Princípios contratuais. Princípios sociais dos contratos. Revista Jus Navigandi, ISSN 1518-4862, Teresina, ano 18, n. 3750, 7 out. 2013. Disponível em: <https://jus.com.br/artigos/25359>. Acesso em: 18 mar. 2017.

LÔBO, Paulo Luiz Netto. Princípios sociais dos contratos no Código de Defesa do Consumidor e no Novo Código Civil. Revista de Direito do Consumidor. vol. 42/2002, p. 187-195, abri-jun/2002.

MARQUES, Cláudia Lima. BENJAMIN, Antonio Herman V.; MIRAGEM, Bruno. Comentários ao Código de Defesa do Consumidor (LGL\1990\40). 3. ed. rev., atual. e ampl. São Paulo: RT, 2010.

MARQUES, Cláudia Lima. BENJAMIN, Antônio; MIRAGEM, Bruno. Código brasileiro de defesa do consumidor comentado pelos autores do anteprojeto. 2. ed. rev., atual. e ampl. São Paulo: RT. 2006.

MARQUES, Cláudia Lima. Contratos no Código de Defesa do Consumidor. 6. ed. rev. atual, e ampl. São Paulo: RT, 2011.

MARTINS-COSTA, Judith. A boa-fé no direito privado: sistema e tópica no processo obrigacional. São Paulo: RT, 1999.

NISHIYAMA, Adolfo Mamoru. A proteção constitucional do consumidor. 2. ed. rev. atual. e ampl. São Paulo: Atlas, 2010.

PEREIRA, Caio Mário da Silva. Instituiçôes de Direito Civil: Contratos. v. 3. 21. ed. Rio de Janeiro: Forense, 2017.

TARTUCE, Flávio. Direito civil: teoria geral dos contratos e contratos em espécie. v. 312. ed. rev., atual. e ampl. Rio de Janeiro: Forense, 2017, p. 597.

TEPEDINO, Gustavo. Temas de direito civil. Rio de Janeiro: Renovar, 1999, p. 122.

USTÁRROZ, Daniel. Contratos em espécie. São Paulo: Atlas, 2015. 